\title{
Rwandan war threatens gorilla research project
}

Washington. A civil war in Rwanda has forced gorilla researchers to flee the country and threatens to disrupt a 25 -year record of observations begun by primatologist Dian Fossey.

\section{IMAGE UNAVAILABLE FOR COPYRIGHT REASONS}

The Karisoke Research Center in Rwanda.

The ransacking on 18 February of the Karisoke Research Centre in the Volcano National Park and the Volcano Veterinary Centre by soldiers of the Rwandese Patriotic Front followed ten days of violence in and around the previously protected animal sanctuary. Five foreigners (two British, one German and two US scientists) were evacuated safely after being trapped for five days at the centre, and five days later 13 Rwandese workers fled before the advancing soldiers, who shot out windows and looted the single-storey buildings. The civil war began in 1990 , but both the rebels and the government had pledged to keep fighting away from the area.
Some 300 mountain gorillas, nearly half the global population, live in the park, according to Dieter Steklis, director of the Karisoke centre, and the death of even a few females could have a major impact on the population. The centre, sponsored by the Dian Fossey Gorilla Fund, studies two groups of 36 and 18 animals and tracks three other groups that are visited by tourists. (The Morris Animal Foundation's veterinary centre monitors the health of the entire population.)

Steklis is also concerned that the trust of the two research gorilla groups in humans, which takes years to develop, may be shattered by the events of the past few weeks. "We're talking

about animals Dian knew personally", Steklis says about the work of Fossey, who was killed in 1985. The loss of such individuals and their life-long records would be a scientific tragedy, he says.

The Rwandese who fled the advancing soldiers reported finding a great deal of gorilla blood as they crossed the trail of one of the gorilla groups, says Steklis, adding that the workers are trying to return to check on the gorillas. Steklis says that the animals are endangered not just by gunfire but also by the illegal hunting of antelopes by both civilians and soldiers, an activity that increases sharply when there are no patrols.

Jenna Roberts

\section{UK engineering curriculum revised}

London. The Science and Engineering Research Council (SERC) is planning a major shift in the training of postgraduate engineers that will offer courses and doctorate schemes with much greater practical content and industrial involvement.

A review carried out by the education and training committee of the council's engineering board, and published in London on 1 March, supports moving away from the present three-year university-based $\mathrm{PhD}$ taken by most postgraduate engineering research students. The committee also recommends that funding for one-year MSc courses be reduced by 30 per cent and that the money be used for modular postgraduate courses for those already working. It also proposes training vouchers, worth $£ 400$ each, for SERC-funded $\mathrm{PhD}$ students for short courses aimed at broadening their range of technical and social skills.

"We must maintain a proportion of engineering graduates in traditional postgraduate work", says James Powell, professor of engineering at Brunel University and chairman of the committee. "But we must shift the balance more towards the engineering side if we are to get the proper integration of theory and practice."

The report recommends that the SERC should aim to have 30 per cent of postgraduate students studying for the new engineering doctorate. Money is a limiting factor, according to Powell, who says that "we would be more bullish if the government were to give us more support". David Dickson

\section{NSF rethinks its proposal to revise page-charge rules}

Washington. A proposal by the US National Science Foundation (NSF) to allow its grants to cover page charges in commercial journals has tapped into a vein of complaints about the pricing of journals and has opened a debate on ways to help libraries defray soaring costs.

The NSF proposal, which has attracted more than 40 responses since it appeared in the Federal Register last December, was a modest attempt to restore balance to a 60 year-old system that allows NSF grants to be spent on page charges in journals published only by nonprofit organizations such as professional societies. The rule was implemented to help societies survive the depression of the 1930 s by subsidizing a part of their publishing costs, and page charges remain an important source of revenue for some scientific organizations.

Last autumn, a publishing company that does not now make page charges questioned the fairness of the rule and suggested that NSF should stop paying all page charges and instead find a way to give the money directly to academic libraries. But NSF chose to correct the perceived unfairness by making no distinction between commercial and non-profit organizations, bringing it in line with the National Institutes of Health.

"We intended to find a vehicle for the NSF to reallocate the money, and instead they are addressing a small section of the issue and precluding a change to abolish page charge payment", says Leslie Parks of the Susan Davis Company, a consulting firm hired by the publishing house.

Most commercial publishers do not make page charges. Four commercial publishers supporting the change emphasized in letters to NSF that they did not plan to adopt page charges but that reforms are needed in the way in which libraries are funded.

The American Geophysical Union (AGU), whose journals are subsidized by page charges, strongly objects to the proposed change, saying that the new policy would encourage commercial publishers to institute page charges, spreading the money over a larger pool and reducing revenues for journals published by non-profit organizations. But William Kaula, a geology professor at the University of California, Los Angeles, says that incentives at present actually favour commercial publishers by allowing scientists to use their money for other things and that page charges in commercial journals may encourage researchers to submit papers to AGU publications

NSF has decided to take more time to digest the unexpectedly large volume of responses and has set no deadline for a decision. 